This is the author's Post-print version (final draft post-refereeing as accepted for publication by the journal). The definitive, peer-reviewed and edited version of this article is published as: Varady D., Kleinhans R. \& van Ham M. (2015) The Potential of Community Entrepreneurship for Neighbourhood Revitalization in the United Kingdom and the United States. Journal of Enterprising Communities: People and Places in the Global Economy 9(3), 253-276. DOI: http://dx.doi.org/10.1108/JEC-01-2015-0009

\title{
The Potential of Community Entrepreneurship for Neighbourhood Revitalization in the United Kingdom and the United States
}

David P. Varady, School of Planning, University of Cincinnati, Cincinnati, Ohio, United States, david.varady@uc.edu

Reinout Kleinhans, OTB - Research for the Built Environment, Faculty of Architecture and the Built Environment, Delft University of Technology, Delft, The Netherlands

Maarten van Ham, OTB - Research for the Built Environment, Faculty of Architecture and the Built Environment, Delft University of Technology, Delft, The Netherlands \& Centre for Housing Research, School of Geography and Geosciences, University of St. Andrews, University of St. Andrews, Scotland, UK

\begin{abstract}
Purpose - The global economic crisis has had a major impact on government spending for urban regeneration. In the context of these austerity regimes, in many European countries, community entrepreneurship and active citizenship are increasingly considered as a means to continue small-scale urban revitalisation. This paper investigates recent literature on both British community enterprises (CEs) and American community development corporations (CDCs). The aim is to assess the current potential of community entrepreneurship in neighbourhood revitalization in the United States and the United Kingdom.

Design/methodology/approach - Starting from a seminal article, this paper reviews literature focusing on the role of CEs and CDCs in neighbourhood revitalization. Differences and similarities are analysed, taking into account national context differences.

Findings - While CDCs have a relatively successful record in affordable housing production in distressed areas, CDCs are fundamentally limited in terms of reversing processes of community decline. CEs in the UK have focused on non-housing issues.

Research limitations/implications - This paper asks the question what CEs can learn from CDCs in terms of scope, aims, strategies, accountability, assets and partnerships with public and private actors. However, a systematic literature review has not been conducted.

Originality/value - Our comparison reveals similarities but also differences with regard to aims, organizational characteristics, co-operation on multiple scales, and community participation. Apart from lessons that can be learned, we provide recommendations for further research that should cover the lack of empirical evidence in this field.
\end{abstract}

Keywords: Community development corporations, community enterprises, neighbourhood revitalization, entrepreneurship, urban regeneration, United States, United Kingdom.

Article Classification: Literature Review 


\section{Introduction}

The global economic crisis, which started in 2008, has had a major impact on societies on both sides of the Atlantic. Governments have implemented budget cuts and austerity measures in all areas of policy, including neighbourhood regeneration. Many large neighbourhood interventions of the past decades in deprived communities have either come to a conclusion or have been cut (Zwiers et al., 2014). The crisis has spurred a new ideological discourse of active citizenship in many European countries, as an alternative to government intervention and spending. The aim is to recast state-citizen relations and promote civil society and to help citizens to help themselves, especially in deprived communities (Wells, 2011). In this context, resident-organized and social entrepreneurial activities are increasingly seen as solutions for deficiencies in public services and neighbourhood regeneration efforts.

In the United Kingdom, as of 2012, local authorities had their budgets reduced by 4 billion pound, and Community-based organizations are being asked to fill in the gap (Bailey, 2012; Hastings et al., 2012). The government has introduced the 2011 Localism Act, which contains a wide array of measures to devolve powers to councils and neighbourhoods and give local communities greater control over local decisions like housing and planning (DCLG, 2011a). Urban regeneration strategies have been replaced by a 'localist' (DCLG, 2011b, 2012) approach to regeneration, with an emphasis on local economic growth, community-led regeneration and reforms in public service provision by local authorities, favouring private and community entrepreneurship (DCLG, 2011b, 2012). Although not a new phenomenon, Community Enterprises (CEs) - social enterprises run by local people for the benefit of their local community - are seen as an important vehicle for urban regeneration. Also other European countries, such as the Netherlands (Meerkerk et al., 2013), Germany (Zimmer and Bräuer, 2014), Norway (Bjørnå and Aarsæther, 2010), and Sweden (Gawell et al., 2009; Sundin, 2011), are increasingly putting emphasis on community-led urban regeneration, and show an interest in the concept of community-based entrepreneurship (see also Ratten et al., 2010).

The concept of community-led regeneration has been around for a while in the United States, and received a particular impetus by the work of Kretzmann and McKnight (1993) on Asset-Based Community Development (ABCD). American community development corporations (CDCs) are community-based organisations that have close ties with deprived neighbourhoods and strive to improve the physical, social and economic conditions in these areas (Stoecker, 1997; Cowan et al., 1999).

Within a larger debate on financial austerity and state retrenchment, the 'localist' approach has been critiqued on both sides of the Atlantic. Minnery (2007, cited in Schatz, 2013, p. 103) notes that American localism has its "dark side"; when neighbourhood groups are expected to carry out neighbourhood revitalization strategies with minimal funding this "marginalizes" the efforts financially and bureaucratically. Thus, this [type of devolution] implies "lessened commitment" (Beauregard, 2013, p. 241). Second, struggling US Community Development Corporations (CDCs) in 'down-and-out' areas serve as "scapegoats for abdicated federal responsibility" (Scally, 2012, pp. 712-713). Many American politicians have been overoptimistic about devolution in that they have failed to realize that CDCs need external support, for example to attract professionals as CDC directors (Scally, 2012/2013). Similar criticism can be heard in the UK, where some see localism as nothing more than funding cuts in disguise, hitting those in deprived neighbourhoods hardest (see e.g. Kisby, 2010).

Until recently, there have been few substantial academic efforts to compare forms of community entrepreneurship across the Atlantic in the context of urban regeneration. Bacq and Janssen (2011) observe a transatlantic divide in the way social entrepreneurship is 
approached, due to different conceptions of capitalism, the government's role and in particular geographic and sociological criteria, such as the concept of 'community'. In a recent review, Nick Bailey (2012) asserts that British CEs need to learn from the successes of American CDCs since they are basically similar: “... whilst the UK political economy is moving towards less state intervention and more community self-help [as is also the case in the US], the community development corporations in the USA provide an indication of the future direction community enterprises might take in the UK as part of a broad trend towards civic capacity building" (Bailey, 2012, p. 1). We argue that also other European countries can learn from comparing US and UK experiences with community entrepreneurship.

This paper provides an overview of CDCs and CEs, and analyses their differences and similarities, while taking into account substantial national context differences (as suggested by Ratten et al., 2010, p. 3 and Bailey, 2012). The aim is to assess the current potential of community entrepreneurship in neighbourhood revitalization in the United States and the United Kingdom. This paper is written from a European perspective and we ask the question what CEs can learn from CDCs in terms of scope, aims, strategies, accountability, assets and partnerships with public and private actors. We not only analyse why, but also how the issues under study appear in various community contexts, in order to do justice to the interactions of CDCs and CEs with their environment (see also Dana \& Dana 2005, p. 81). To answer these questions, we will analyse these two types of community organizations with respect to (1) definition and evolution over time, (2) key conditions for regeneration impacts, and (3) impacts on community revitalization. It must be noted that this paper does not attempt to cover the entire community development literature (see for example Glickman and Servon, 2003: Keating et al., 1991).

The next section on American CDCs first distinguishes the term "community development corporations" from related terms and describes the evolution of CDCs; identifies the key conditions for regeneration impacts and assesses the revitalization outcomes produced by CDCs. In the third section we examine the same issues in relation to British CEs, but it is important to note that our review of the CE literature is based primarily on Bailey's (2012) article. We conclude the paper with some lessons for British CEs based on our assessment of the American CDC literature and recommendations for future research.

\section{Community Development Corporations (CDCs) in the US}

\subsection{Definition and evolution over time}

Apart from US-UK differences in welfare state arrangements and policy history, one of the problems involved in comparing British community enterprises with American community development corporations is the different terminology used on each side of the Atlantic. The terms "social housing" and "social enterprises" - as widely used in the UK - are absent from American discussions. Bratt (2012, p. 439) tries to clear up this linguistic complexity by (1) reminding us that a social enterprise is "a business with primarily social objectives whose surpluses are principally reinvested for that purpose in the business or the community, rather than being driven by the need to maximize profits for shareholders and owners," (2) that "non-profit housing" (an American term) is a type of "housing social enterprise", and (3) that CDCs are a type of non-profit housing organization that develops and maintains affordable housing for a particular area using community-based leadership, although many are also engaged in economic development and social services.

Like British community enterprises, CDCs own a community asset, in this case lowincome housing. Rather than profit maximization, the goal of the CDC is to provide lowincome housing over the long course in areas of the city that for-profit developers have 
generally abandoned. American CDCs use income from rental properties as well as funds from other sources to develop and maintain these properties. Only a relatively small number of CDCs derive income from leasing out commercial or industrial properties. CDCs emerged when the federal government launched the War on Poverty in the mid-1960s. Federal policy sought to empower the poor through 'maximum feasible participation.' Since 1980, the federal government has relegated increased responsibility to localities while simultaneously reducing funding (Accordino and Fasulo, 2013).

In contrast to the secondary role played by British CEs in neighbourhood regeneration (see section 3), US CDCs have played a key role. Since the 1980s CDCs have sought to achieve comprehensive, bottom-up redevelopment by empowering "whole communities through comprehensive treatment of social and physical conditions [...] measuring success in terms of physical redevelopment and community regeneration, participation, and empowerment" (Stoecker, 1997, p.4, cited in Cowan et al., 1999, pp. 327-328). These CDCs have been expected to better relate to their local constituency while at the same time stimulating private investment in the inner city (Scally, 2012).

The most recent survey providing an estimate of the number of CDCs found about 4,600 such organizations (NCCED, 2005, cited in Bratt et al., 2012). CDCs have produced or rehabilitated more than 1,252,000 units of housing up till 2005 (NCCED, 2005). CDCs and the other large non-profit housing producers have provided affordable housing opportunities to nearly 1.5 million households, almost one-third of the social housing sector in the US. These positive results are counterbalanced to some degree by the fact that many CDCs have a small staff, produce or rehabilitate few units annually, and that many organizations eventually fail.

CDCs and other community-based organizations have been moving in the direction of increased comprehensiveness for several decades. The overwhelming majority of CDCs combine their physical and business development with other initiatives (NCCED, 2005; Dewar and Thomas, 2013). More than 50 percent of CDCs report that they offer homeowner counselling, budget/credit counselling and education/training. To pay for their broadened scope some CDCs have served as consultants to less experienced non-profit groups or have created real estate firms that generate commissions from sales). Other non-profits that have experienced difficulty accessing capital with which to purchase land and buildings (e.g. Mayer and Temkin 2006, cited in Bratt, 2008), have surmounted this obstacle by developing partnerships with land-rich entities, such as churches (Bratt, 2008, p. 340).

\subsection{Key conditions for revitalization impacts}

CDCs vary in their capacity. The success of any particular CDC (in terms of producing or rehabilitating housing or to carry out related economic development and social service programs) is influenced by characteristics of the organization itself, characteristics of the surrounding neighbourhood, city and region, and indirectly by the influence of CDCs through state and national CDC networks. In general, relatively little is known about the relative importance of these four sets of factors (Cowan et al., 1999).

\section{Organizational characteristics}

CDC success has been linked to a high level of sophistication in packaging financing from multiple sources and savvy in dealing with other neighbourhood organizations, local government, and financial intermediaries (Accordino and Fasulo, 2013) as well as a clear focus and sense of purpose (Cowan et al., 1999, p. 338). Cowan et al.'s 1999 study is one of the few empirical analyses of factors influencing success of CDCs. They identified five factors that promoted CDC efficiency: (1) an average direct investment of over \$1.25 million over the study period (highlighting the existence of a threshold beyond which the CDC 
benefits from economies of scale), (2) executive director tenure (spotlighting the benefits of organizational stability), (3) staff size (implying that the relationship is non-linear, i.e. showing that the benefits of scale has limits), (4) formal training of staff, board members and volunteers (i.e. improved knowledge leads to better performance), and (5) the number of activities (suggesting that a broader scope may lead to greater name recognition and greater external funding). Unfortunately, Cowan et al.'s study did not study the impact of the board of directors including the influence of board's diversity on effectiveness. Furthermore, they did not study the role of the relative to the role of the director, in establishing the mission of the CDC, in governing the organization, and in establishing the importance of the relationship between the board and the executive director in influencing agency effectiveness. Motivation has also been a factor with CDC directors tending to place a higher value on altruistic benefits than on monetary rewards (Cowan et al., 1999). However, because CDCs have become more business-like, this means that higher salaries will be needed to attract qualified candidates.

\section{Co-operation on multiple scales}

Previous writings suggest that a CDC's prospects for success will be greater if (1) the neighbourhood has strong social networks since this would make it easier to recruit volunteers (2) if the neighbourhood is in the early stages of decline (see subsections on targeting and outcomes below), and (3) if the neighbourhood contains significant assets and magnets, such as government facilities, hospitals and universities ('feds, meds and eds'). It is in the interest of the latter three entities to provide technical and financial assist to CDCs either directly or indirectly.

The track record of CDCs (in terms of housing production) in shrinking cities like Detroit has not been impressive. Low demand, a result of socially mobile families being pulled to the suburbs, makes it difficult if not impossible to find moderate- income renters and homebuyers for new or rehabilitated homes (Beauregard, 2013; Ryan, 2013; Thomas, 2013). However, CDCs in some shrinking cities do better than CDCs in other ones; as Erickson (2009) indicates, it is important, that CDCs become integrated into the stable networks of support for low income housing production.

Chicago's New Communities Program (NCP) highlights the importance of cooperative relationships on the scale of the city or metropolitan area. The NCP "support[s] relationships among groups, including $\mathrm{CDCs}$, promote[s] their capacity, and help[s] ensure that they complete projects identified in plans." (Greenberg, 2010, p. 47, cited in Rich, 2014, p. 83) The federal government's Community Development Block Grant program (CDBG) acting through CDCs and other community organizations has the potential to shift from the old paradigm of discrete projects to one that emphasizes "collaborative, comprehensive community-based initiatives." (ibid. p.83)

Finally, CDCs have attempted to scale up beyond the locality by linking the local through a national network (National Congress of Community Economic Development), then expanding CDC spaces of engagement through state policy networks; and most recently by developing a new national network of networks, the National Alliance of Community Development Associations, NACDA (Scally, 2012). For CDCs that operate in politically contentious states, or within institutionally weak community development environments, national networks may be the most feasible opportunity for CDCs to shape their policy environment beyond the local (Scally, 2012).

\section{Comprehensiveness and viability}

Since the early 1980s, CDCs have gone beyond producing housing alone and have emerged as leaders in providing 'housing plus' services. "Professional non-profit housing developers [...] came to acknowledge that their tenants might not be able to stay in their units without various 
types of [social] services." (Bratt, 2012, p.445). This housing-plus approach to subsidized housing involves providing not only the bricks and mortar, but also job training, social service programs and economic development activities (micro-enterprise development) and so forth (Bratt, 2008, p. 101). In fact, CDCs seem to be moving closer towards CEs in terms of comprehensiveness (see section 3), "blending the roles typically associated with the public and market based for-profit sectors." (Bratt, 2012, p. 447). CDC success increasingly depends on the ability to secure funding from outside sources including the federal government, state funded housing programs, private foundations, and national non-profit intermediaries. With their growing dependence on these sources, CDC directors and staff have had to develop sophisticated financial skills to apply for the complex Low Income Housing Tax Credit (LIHTC) program and to assure funders that they have the ability to measure their effectiveness based on social, cultural and environmental outcomes along with traditional economic ones (see Scally, 2012/2013). Trying to carry out a wider scope of activities in the context of decreased federal funding, CDCs face Rachel Bratt's "quadruple bottom line":

"... the financial viability of the development, the social and economic needs of the residents living in the housing, a sensitivity to the way the housing fits into the larger fabric of the neighbourhood and contributes to neighbourhood viability; and the housing should be environmentally sensitive and sustainable as possible, which involves minimizing the use of non-renewable energy resources and striving to reduce transportation needs". (Bratt, 2012, pp. 443-444)

The quadruple bottom line creates three types of tensions. First, a focus on financial viability may work against meeting the needs of residents. If a CDC decides to offer social services, how will it pay for them? Federal government regulations prevent non-profits from using excess revenues from a particular development to subsidize 'housing plus' services (Bratt 2008, p. 107). Ironically, this is precisely how CEs are supposed to achieve a sound business model (see next section).

Second, a focus on economic development and environmental sustainability may undercut equity planning (meeting residents' needs). Berke and Godschalk's 2009 analysis of Baltimore, Buffalo, Cleveland and Philadelphia (cited in Schilling and Vasudevan, 2013) showed that in all four cities social issues took a less important role than environmental and economic development policies.

Third, raising capital from the private and public sectors may conflict with community organizing (e.g. fighting City Hall and financial institutions). Specifically, CDC directors dependent on bank loans or government grants may be less likely to participate in local protest movements (Stoecker, 1997, cited in Bratt, 2012). Similarly, the quest for greater CDC efficiency would favour the multi-local CDC approach advocated by Stoecker (1997), i.e. CDCs covering an entire city rather than a particular community. A risk is the possible decrease in neighbourhood input into CDC decision making. If one CDC serves multiple areas, residents in individual neighbourhoods may have less voice in setting policy.

\section{Targeting}

Targeting implies a focus of subsidies on higher-capacity declining communities (i.e. ones with more effective CDCs, along with a concentration on specific subareas within these communities, in order to strengthen the prospects for neighbourhood improvement. Currently, there is widespread consensus among housing funders and housing researchers that geographic targeting will most likely lead to neighbourhood improvement. Research shows that concentrated Community Development Block Grant (CDBG) funding (provided by the federal government) contributes to neighbourhood improvement but this is most likely to 
occur in homeownership neighbourhoods (Rohe and Galster, 2014; see also Bostic, 2014; Briggs, 2014; Galster et al. 2004, 2006; Pooley, 2014; Thomas, 2013). Although community development funders are fond of the idea of targeting, "political expediency dictates that elected officials spread federal CDBG [and other revitalization] funds like peanut butter on bread [italics in original] mollifying all, but fixing none because of the lack of a critical mass of resources in any area" (Joice, 2010, cited in Accordino and Fasulo, 2013, p. 617; see also Thomas, 2013).

With two significant exceptions, housing scholars generally have not clarified whether communities with strong CDCs ought to be prioritized in the future. Ehrenfeucht and Nelson (2013, p.169) note that post-Katrina New Orleans provided a political environment supportive of strategic targeting where foundation funds went to externally endowed CDCs with demonstrated capacity rather than to less experienced indigenous organizations. Brooks and Sinitsyn (2014) observe that if Community Development Block Grant (CDBG) funds, the largest source of funding for CDCs, were allocated exclusively to the poorest parts of the poorest neighbourhoods without regard to community organizational capacity, the city's CDBG program would lose critically needed political support from the more politically powerful CDCs located in the less distressed poor neighbourhoods. Hence, future research should investigate the best ways to achieve a balance between strategic targeting and needsbased targeting.

\section{Community participation}

The growth of CDCs in America is due, in large part, to the presumed relationship between these organizations and the community. However, existing scholarship provides at best, weak support for assumptions about either levels of involvement or the benefits of participation to low-income residents in CDCs.

First, because communities are not monolithic entities, it is questionable whether CDCs can represent a "community." They consist of residents (owners as well as renters), absentee landlords, small businesses, and larger commercial outlets. Consequently, on any issue it is unlikely that these groups can find common ground and be represented by a CDC (Bratt, 2008). The same applies to (potential) entrepreneurs within CDCs, who may vary as well. Following Dana (1995, p. 60), a first type of entrepreneurs may be 'opportunity seekers', who are driven by culturally acquired values such as thrift and frugality, while others have specific psychologhical characteristics such as a high sense of achievement or deliberately aim for social changes within 'the community'. A second type may involve residents who lost their (regular) job and subsequently venture into entrepreneurial activities to increase their income and social status and decrease their 'marginality in society'. A third type includes entrepreneurs who identify a market opportunity, either by 'stumbling across' it or by alertness. Because of this diversity within communities and CDCs themselves, community activists and CDC directors can hardly speak for "their community" (Fainstein, 2010).

Second, attaining high levels of citizen participation is more difficult than most practitioners and academics realize. The complexity of funding may discourage residents from participating (Bratt and Reardon, 2013). Although ideally, residents should be heavily represented on CDC boards, in reality resident participation in CDC boards is limited (Bratt and Reardon, 2013). In some cases, a majority of board members are outsiders (bankers, academics, city officials), a reflection of the CDCs' need to access outside financial resources. CDCs can use community events as a tool for 'involvement'.

Third, little empirical evidence exists to show that involvement in CDCs enhances individual sense of efficacy and hence increases the prospects for social mobility (Bratt and Reardon, 2013). CDCs may succeed in helping some lower income renters to become owners but it is debatable whether this type of tenure change constitutes empowerment. While some 
CDCs create stronger alliances within and outside CDC neighbourhoods (a measure of greater community empowerment), this may reflect the efforts of entrepreneurial CDC directors rather than the influence of poor residents.

Fourth, a high level of community participation (i.e. community control) does not necessarily translate into a higher quality of life. Some CDCs may become so preoccupied with community control that they lose sight of the need for economic development (see Scally 2012/2013). Furthermore, a community control focus can lead to resident frustrations because of an inability to achieve high expectations (Scally 2012/2013), as well as parochialism, corruption (Fainstein, 2010, p. 67) and anti-social attitudes (Bratt and Reardon 2013). In such cases, a phenomenon called community disentrepreneurship may appear. Disentrepreneurship refers to a situation in which "a community creates, either systematically or by accident, an environment unsuitable for the establishment or sustainability of existing entrepreneurial activities. It may do this through public policy initiatives that penalize or prohibit entrepreneurial activities, by promoting cultural values and norms that discourage entrepreneurship, or by failing to create the required legal, institutional, and structural environment necessary for entrepreneurship to become established" (Honig and Dana, 2008, p. 11). As a result of the aforementioned problems, resident management in public housing is no longer trumpeted by housing advocates (Vale, 2013). Less radical approaches (e.g., partnership arrangements between CDCs, other non-profits like universities, private firms, and local government) may be preferable to community control (Bratt and Reardon 2013).

\subsection{Impacts on community revitalization}

Can CDCs spur community revitalization? On the one hand, advocates believe that CDCs can promote community revitalization through new housing or rehabilitation combined with public infrastructure improvements-especially if these physical improvements are supplemented with social services (i.e. 'housing plus programs', see Bratt, 2008). On the other hand CDC critics assert (1) that CDCs are almost unnecessary-that "the private sector could and would pick up the slack if CDCs faded into oblivion" (Scally, 2012/2013; see also DeFilippis, 2004; Fraser et al., 2003; Husock, 2003; Rusk, 1999), (2) that CDC efforts are so small and marginal that they are unable to counteract the effects of concentrated poverty (Newman and Schnare, 1992), the interrelated processes of racial and economic decline, wasteful suburbanization (Briggs, 2014), gentrification (Fainstein, 2010) and globalization (the loss of inner city-jobs to the suburbs and beyond overseas, DeFilippis, 2010), (3) that CDC programs could lead residents to define themselves as 'welfare dependent' thereby undermining their sense of self-worth and cause them to see deficiencies in themselves, their neighbours, and their communities (Bratt, 2008 based on Kretzmann and McKnight, 1993), and (4) that householders in CDC neighbourhoods who achieve mobility are likely to move out.

Because there has been so little empirical research on the impacts of CDCs, and because it is difficult to separate the impact of CDCs from other community development programs, it is worth addressing the question of how effective America's Community Development Block Grant (CDBG) program has been in promoting revitalization. Existing writings offer conflicting results. Two Urban Institute studies (Galster et al., 2004; Walker et al., 2002) "found evidence of significant improvement in neighborhoods where CDBG funding was concentrated. The authors found that tracts with above-average CDBG spending per poor resident over the three-year study period (1994-1996) had significant positive relationships between CDBG spending and neighborhood outcomes, as measured by median home mortgage loan originations, mortgage application approval rates, and the number of businesses" (Rich, 2014, p. 71). Similarly, Pooley's 2014 article suggested the existence of a threshold of CDBG funding beyond which increases in public investment were associated 
with sharp increases in housing values. At the same time, a recent evaluation of the CDBG program concluded that it has demonstrated little effectiveness in revitalizing poor communities (Center for Effective Government, 2005, cited in Rohe and Galster, 2014).

Two recent evaluations of community development efforts with entrepreneurial elements highlight the challenges to inner-city revitalization. DeLuca and Rosenblatt's 2013 evaluation of the Enterprise Foundations' Sandtown-Winchester Neighborhood Transformation Initiative (West Baltimore) highlights the resiliency of social problems in high poverty and racially segregated neighbourhoods. Unfortunately, DeLuca and Rosenblatt do not discuss the efforts of CDCs so it is impossible to assess their role in the limited revitalization that took place. Clearly, it is important to assess the role of CDCs in future studies of this kind.

Monti and Burghoff's 2013 article highlights the limited prospects for community revitalization when it is carried out in conjunction with public private partnerships. The authors tracked social and economic changes in five communities in St. Louis between 1970 and 2000 - where redevelopment was undertaken by public-private partnerships — and compared the progress of redevelopment areas against nearby 'control sites.' The effects were more apparent at some redevelopment sites as compared to others and the spillover effects of redevelopment were limited to immediately surrounding sub-neighbourhoods. Equally important, redeveloped areas managed to retain many of their established low-income minority residents and/or replace them with people who were very much like them-in part because of the efforts of these large institutional partners to maintain a population mix. While Monti and Burghoff do not discuss CDCs explicitly, they conclude that without the long-term publicprivate partnership, the middle part of the city of St. Louis would be much less vital than it is today." (p. 529). Similarly, Scally (2012, pp. 715-716) asserts that 'but for' CDCs [neighbourhoods would] be considerably worse off than they are today.

The existence of hundreds of gentrifying communities across America (and in other developed countries) shows that decline is not inevitable; in some cases the process may be reversed, albeit with costs (as well as benefits) for long-term, low-income residents (Freeman, 2006). While it is impractical for CDCs to "stop" gentrification, they may address the problem of displacement by enhancing the stock of socially managed housing and by implementing programs promoting social interaction across class lines (DeFilippis et al., 2010). Unfortunately, few cases studies exist of CDCs attempting to create stable mixedincome communities in areas experiencing gentrification.

\section{British Community Enterprises}

\subsection{Definition and evolution over time}

Like other social enterprises, British community enterprises (CEs) are not-for-profit organizations which operate commercially. The key distinguishing characteristics of CEs are owning and managing properties, retaining profits for the good of the community and being locally accountable (Pearce, 2003). According to Bailey (2012), community enterprises receive income from their assets (i.e. property management) and then recycle this income (rents, less management costs and contributions to reserves) into a range of social, economic or cultural programs or activities that address a certain need in a place-based community or tackle a perceived service deficiency, whether or not as a result of austerity programs. Bailey (2012, pp. 6-7) distinguishes between three categories of community enterprises: (1) Village halls (with approximately 10,000 spread throughout England); (2) Community development trusts involved in the provision of housing, workspace and training, retail, health and sports 
facilities and the delivery of contracts for nurseries and social services; and (3) Former partnership regeneration projects, e.g. the New Deal for Communities (NDC, see Lawless, 2011) or Neighbourhood Management Pathfinders.

The following four cases from Bailey's 2012 article highlight the broad scope of British CEs which are located in both rural localities and urban neighbourhoods. The first case is the Caterham Barracks Community Trust (Caterham, Surrey), which played a major role in redoing a redundant army barracks in the middle of a small village, in a rural area within London commuting distance, into an "urban village". This was developed with 400 houses and flats, business premises and a range of community facilities. (p. 18). The second case is the Creation Development Trust (Blaengarw, South Wales), which "has developed a series of social enterprises [e.g. the Blaengarw Workmen's Hall, a 250-seat arts and community venue], projects and events that have made regeneration a reality for this mining town..." (p. 20). The third case is the Manor and Castle Development Trust, which serves one of the most deprived areas in Sheffield, a formerly industrial city. The trust has two wholly owned subsidiary companies, one which operates a building containing serviced offices and another which manages land on which housing with government regeneration funding was built. The fourth case discussed by Bailey (2012) is the Westway Development Trust (WDT), which serves North Kensington, London, "the most deprived part of an otherwise very affluent borough in inner London. The Westway Development Trust provides sports facilities on 9 hectares of land under the Westway Flyover [an elevated highway] land transferred to the Trust by 'Transport for London' although it was originally owned by the Greater London Council abolished in 1986. (p. 26)

These case studies illustrate the type of activities CEs are involved in, but they also suggest that there is a niche for these community-based organizations in relatively affluent suburban locations, rural and sea-side villages (see also Williams, 2011), as well as depressed inner city locations with the more traditional array of social, economic and environmental problems. Although some scholars (e.g. Thake, 1995 cited in Bailey, 2012) have argued that CEs could make a major contribution to community regeneration by forming partnerships between other organizations in the voluntary and community sectors and public sector bodies, CEs have generally not been seen as central to government-initiated regeneration processes.

\subsection{Key conditions for revitalization impacts}

As with CDCs, four sets of factors influence the success of community enterprises in the context of urban regeneration: (1) characteristics of the organization, (2) cooperation on multiple scales, (3) comprehensiveness and viability, (4) targeting, and (5) community participation.

\section{Organizational characteristics}

Bailey (2012) identifies three key organizational characteristics. The first is the skill level and the level of entrepreneurship of the director and other staff. The social entrepreneur, who is most often the director "... needs the skills of the entrepreneur to identify opportunities and ways of exploiting them, they need a clear vision about the social, economic and environmental objectives of the organization, and an ability to motivate staff, the directors and the wider community in order to sustain the organization and to ensure it prospers" (ibid. pp.14-15). Some trusts are much more entrepreneurial than others and create complex developments involving cross-subsidization. For example, Coin Street Community Builders (CSCB, London) is already well known for their mixed use Oxo Tower development which was completed in 1996. The commercial residential development funds most of the capital cost and all of the revenue subsidy required for leisure and recreational programs (ibid. p. 29; see also Fainstein, 2010, pp. 124-125). 
The second factor is the level and quality of voluntary efforts. Generally, "the best outcomes arise where individuals take on responsibilities and play roles which generate satisfaction and a sense of achievement for themselves" (ibid. p. 18; see also Smith, 2012). The third factor is the size of the community enterprise. Larger organizations tend to have larger capacity and greater potential for success. "Sources of funding and resources vary enormously between organizations. Some exist on very small donations and other sources, the bigger enterprises gain revenue funding from their own assets which may be let on commercial terms, or from other surpluses (p.28)."

\section{Co-operation on multiple scales}

As in the US, the success of CEs is dependent on cooperation on multiple levels, from the neighbourhood to the nation as a whole. Bailey (2012) emphasizes the importance of social capital in the neighbourhood or locality:

"The primary strength of community enterprise is that it can harness the social capital evident in local communities and use it to achieve positive outcomes through mobilizing volunteers, board members and paid staff. The commitment to the locality and the ability to exploit the tacit knowledge of residents gives the organization added strength and the ability to represent it in other forums. Thus community enterprises are aware of the positive benefits of engaging local communities in order to build capacity and to promote bridging, bonding and linking social capital" (ibid. p. 30; see also Ferri et al., 2009; Smith, 2012).

Unfortunately Bailey (2012) does not provide empirical evidence to support the above assertions, e.g., that communities able to mobilize volunteers are more likely to achieve positive outcomes (however these positive outcomes are defined). In addition the likelihood of success is dependent on neighbourhood social and economic conditions. Take Bailey's example of The Steel Inn operated by the Manor and Castle Development Trust in Sheffield. This was a pub which developed a bad reputation and which experienced a high incidence of anti-social behaviour. The Trust's ability to work with local authorities to produce a young people's resource centre clearly was undercut by the concentration of poverty and related social problems.

The effectiveness of a community enterprise is also dependent in part on the CEs' participation along with other groups in city-wide planning processes and neighbourhood forums. As an example of this type of partnership arrangement, the Lyme Regis Development Trust works closely with the town council and District Council in building on the Lyme Forward Community Plan when opportunities and funding become available (Bailey, 2012, p.22). A similar example is offered by the Caterham Barracks Community Trust, of which a chairman was not only a local resident, but also a district counsellor, and therefore important in creating relations between governmental institutions (the District Council and District administration), the local community and the private developer (Van Meerkerk et al., 2013, p. 1649).

According to Bailey, if community enterprises are to achieve the same level of growth as American CDCs then the UK needs to replicate national intermediaries such as the US Local Initiatives Support Corporation (LISC) which allocate resources and provide technical support to CDCs and related organizations (Bailey, 2012, p.13). In the UK, over six hundred community enterprises are joined in Locality, a leading nationwide network of development trusts, community enterprises, settlements and social action centres. Its vision is "is to make every community a place of possibility - through social action, community enterprise and community asset ownership" (Locality, 2014). For this purpose, it offers expert guidance, a 
range of free tools and further support to community enterprises. Presumably CEs that belong to Locality are more successful in accessing external funding and expertise although this hypothesis has not been empirically tested.

\section{Comprehensiveness and viability}

Most community enterprises aim to achieve the 'triple bottom line' of economically viable operations (being able to meet the payroll), social benefits (including but not limited to more jobs for the unemployed) and high environmental standards (more parks and open space, buildings which reduce energy consumption) (Elkington, 1998, cited in Bailey, 2012). Achieving this triple bottom line creates tensions. For example, acquiring vacant buildings may necessitate costly repairs undercutting the agency's financial viability. There exists considerable variability among community enterprises in terms of their ability to achieve the 'triple bottom line.' Some community enterprises such as Coin Street Community Builders (London) are fortunate in securing assets from the beginning. They are especially privileged if these assets can be acquired at below market value; this may be through transfer from a local government or other public body or as part of negotiations arising from the planning system. Other community enterprises struggle to acquire assets and often find it difficult to obtain commercial loans for acquisition and development if the full market price has to be paid. Accessing capital funding at reasonable interest rates remains one of the major limitations on the growth of this sector. (Bailey, 2012, p. 32). All Bailey's case studies emphasize the financial challenges facing community enterprises in terms of funding and financial risks.

In order to put together complex financial deals necessary to accept the increased responsibilities assigned to them by government, community enterprises have to upgrade their financial skills. Specifically, community enterprise directors "and their boards [need] to identify an opportunity, produce a business plan which works financially, identify possibly multiple funding sources and then to implement the project within budget" (Bailey, 2012, p.28).

\section{Targeting}

In section 2.2, we explained that geographic targeting in the USA context implies that a focus on higher capacity declining communities, along with a concentration on specific subareas within these communities, will improve prospects for neighbourhood improvement (Thomson, 2013; see also Galster et al., 2006, Ryan, 2013). In the UK context, the changing policy context creates a double loading to the concept of targeting. A key aim of the 2011 Localism Act is to pave the way for a wide transfer of powers to communities, neighbourhoods and individuals, for example by a 'Community Right to Buy' (CLG, 2011) that should facilitate the transfer of important private or public assets with a 'community value' to community groups. Citing Kisby (2010) and Lawless (2011), Bailey (2012) identifies several problems of this power-devolving strategy, which are important for the issue of targeting:

“... Second, there is no apparent targeting of the most deprived neighbourhoods which require most assistance in addressing issues of asset transfer. Third, it clearly favours the better organised and generally more affluent areas which already have the skills, knowledge and resources to run community enterprises which can exploit opportunities. Fourth, the reduction of funding for voluntary and community organisations since 2010 has been substantial and therefore the sector is less able to take advantage of new opportunities" (ibid. p.12).

In other words, the government approach seems to be moving away from targeted support to the most deprived areas (often those with limited capacity and also disproportionally hit by 
austerity budget cuts, see Hastings et al., 2012) to a do-it-yourself strategy in which the better equipped community groups have more opportunities to take hold of assets (which are key to the prospects of community enterprises). In fact, this can be considered as an implicit targeting strategy that resembles the US situation in the sense that resources or assets will go to 'areas in need' where the expected 'return on investment' is highest. And the remains of 'traditional' government targeting are hampered by the reduction of funding for voluntary and community organizations. As a result, the key challenge lies with CEs in deprived areas where government sponsoring is about to disappear and where social and cultural capital and abilities are low (compared to middle-class communities).

\section{Community participation}

Community enterprises need to be viewed in the context of earlier neighbourhood regeneration projects. Although participation has usually been stressed as a goal, there has been confusion about who should be involved in community participation and how this would contribute to the achievement of regeneration objectives (Evans, 2008, cited in Bailey, 2012, p.9) Even though these earlier neighbourhood regeneration programs emphasized community involvement, national evaluations demonstrated that, even with additional resources, the proportion of residents directly involved remained limited." (ibid.; see also Lawless, 2011). Rather than rely on direct means such as 'town halls', most community enterprises use informal mechanisms, such as volunteers and word of mouth, in order to encourage greater involvement in the organization. Involvement is also achieved through events and festivals, community cafes and training, or through day-to-day informal influence and persuasion.

A key issue for community enterprises is the representativeness of the boards. With some exceptions noted by Bailey (2012,p. 15), many CE boards are dominated by white men, many of whom are retired. While such boards are clearly not fully representative of the community they may be better connected to the private sector than would be the case if the board were more demographically diverse. "In essence, the organization needs to be able to attract members with a range of appropriate skills, engage the wider public and other stakeholders, and establish systems which are flexible and sustainable in the longer term" (ibid.).

\subsection{Impacts on community revitalization}

CEs often arise through the perception of serious deficiencies in a particular area, such as deprivation, poor health, inadequate housing or a lack of facilities, for which existing agencies are unlikely to provide solutions (Bailey, 2012, p. 26; Peredo and Chrisman, 2006). Somerville and McElwee (2011, p. 323) have argued that community enterprise can be understood in terms of capital that is simultaneously economic, social and cultural, by creating wealth, developing community and transforming local culture. As such, the beneficial impacts on community revitalization may be substantial. However, Bailey (2012, p. 33) asserts that "the impact of community enterprise is very difficult to assess because it operates on so many fronts, works on different timescales, and delivers social, economic and

environmental benefits. In many ways, recording outputs, rather than outcomes, and the perceptions of those directly involved and users is more meaningful but still raises methodological difficulties" (for an extensive treatment of the scope of methodologies in entrepreneurship research, see Dana and Dana, 2005). This explains why much of the 'evidence' he presents is rather anecdotal. Another example shows that it has been easier to report on CE outputs than outcomes. The Caterham Barracks Community Trust "used its funds to establish a range of economic, social, educational, cultural and sports facilities, such as an indoor skate park, a centre for arts and recreation, a cricket field, a children's play area, a nature reserve/community farm, a centre for enterprises and a football club. The Trust 
functioned as a platform or 'springboard' for these user groups to run certain community facilities and it holds an open attitude towards potential user groups" (Van Meerkerk et al., 2013, p.1642). Nevertheless, Bailey is optimistic about the future of community enterprises as long as they adopt a new regeneration model, one "that accentuates the people and their assets as the starting point, rather than negative measures of 'need' and one that builds up the organizational skills of residents" (p. 32). His new regeneration model depends on a high level of citizen participation, something that has been extremely difficult to achieve in distressed neighbourhoods in the UK. The rise of facilitating legal frameworks such as the Localism Act (2011), may support this new model of regeneration, but it is too early to establish the validity of this claim.

\section{Discussion and Future Research}

Nick Bailey's 2012 article on British community enterprises (CEs) asserted that CEs fundamentally resemble American Community Development Corporations (CDCs) and, consequently, that CEs could learn from CDCs. In this paper we have analysed the extent to which CEs and CDCs resemble one another with respect to their evolution, factors affecting success, implementation dilemmas, and track record in promoting community revitalization.

Although both CEs and CDCs are non-profits with a clear spatial focus, and both have attained growing importance due to devolution of responsibilities from the national to local and community levels, they exhibit significant differences. CEs are best known for managing properties transferred to them by government and other entities; to date, they generally do not play a central role in neighbourhood revitalization efforts. In contrast, CDCs emphasize housing construction and/or rehabilitation and CDCs are key actors in neighbourhood revitalization efforts. However, CEs and CDCs are becoming increasingly similar. Some CEs are involved in housing provision. On the other hand, some CDCs (like CEs) are leasing space in commercial and industrial facilities while accepting donated property from land-rich entities such as churches. Similar factors affect the prospects for success of CEs and CDCs: agency size, the level of training and motivation of the director, neighbourhood social capital (which affects the ability to draw volunteers), neighbourhood social and economic problems (inversely); community assets (such as universities, hospitals and government offices), and membership and participation in local and national networks. There is one organizational key difference in the determinants of success. In the US, but not in the UK, there is consensus about the need to pay professional-level salaries to attract qualified directors.

CEs and CDCs are experiencing some of the same dilemmas concerning implementation. First, in both countries there is considerable scepticism about the value of devolution. CEs and CDCs are assumed to take on increased responsibility but without the funding needed to carry out these responsibilities. Their success increasingly depends on the ability to secure funding from outside sources including the (federal) government, state funded housing programs, private foundations and national non-profit intermediaries. Second, in both countries community-based organizations face a series of trade-offs related to the quadruple bottom line; maintaining financially stable operations, offering needed social services, promoting community economic development and maintaining high environmental standards. Third, although both CEs and CDCs prize community participation, the desired levels of participation and the presumed benefits (such as 'empowerment') usually have not been achieved or cannot be substantiated by research.

On the other hand, British and American discourse concerning targeting differs. In the UK, the national government now implicitly targets high capacity communities through the power devolution and do-it-yourself discourse regarding community self-help and asset 
transfers through a Community Right to Buy. Many UK academics object to this form of targeting (Kisby, 2010; Lawless, 2011; Bailey, 2012). In contrast, many American practitioners and scholars advocate "strategic geographic targeting": focusing on highcapacity lower-income communities (within a population of lower income communities eligible for help) and by concentrating projects at block and neighbourhood subarea levels. However, targeting (whether strategic or equity-based) rarely occurs in the US because politicians prefer to spread limited funds over all eligible communities. The discussion on targeting reveals a paradox associated with the new emphasis on active citizenship as an alternative to government involvement in community development: the most deprived communities are the hardest hit by government retrenchment, but have the least capacity to solve local problems. If government funding is most productive in stimulating community entrepreneurship in high-capacity neighbourhoods, should governments then develop 'safety net' policies for communities with the least capacity to solve problems themselves?

The scarce scholarly empirical work on the impact of CEs and CDCs on community revitalization has produced optimistic conclusions but little 'hard evidence.' The lack of information on changes in socioeconomic indicators resulting from CDC activities is understandable. Because information on housing production is more readily available than data on other non-housing objectives such as 'community empowerment' CDCs generally find it easier to show success by focusing on housing production (Scally, 2012/2013). Considerable room for improvement remains until scholars will be able to tease out the role that CDCs play in revitalization efforts and to transfer the lessons of CDC successes or failures from one community to another. The available empirical research suggests that community development programs have generally not been able to counter the forces of decline.

To conclude, British CEs could benefit from American CDCs by: (1) Importing the model of national financial intermediaries such as LISC (see also Bailey, 2012, p.13); (2) Initiating a serious discussion about the need to pay directors professional-level salaries and the implications involved; (3) Making greater use of strategic targeting while simultaneously raising the capacity of CEs in distressed areas; and (4) By replicating sophisticated community development studies (see DeLuca and Rosenblatt, 2013, and Monti and Burghoff, 2013).

Based on the literature review, our paper raises a number of issues that can guide future research. First and most obvious, the very scarce empirical work on the outcomes of CDCs and CEs clearly needs extension. As Bailey (2012, p. 33) has mentioned, these impacts are very difficult to assess because they operate on many fronts, on different timescales, and deliver various social, economic and environmental benefits. Moreover, the impact of CDCs/CEs is in itself difficult to "flesh out" as part of larger community revitalization efforts. To overcome such methodological challenges, the quality of outcome research has to match the sophistication of either quasi-experimental studies like Moving to Opportunity (MTO), or a comprehensive Theory of Change (ToC) approach combined with in-depth fieldwork. In brief, the latter approach meticulously analyses the assumptions behind a certain (policy) intervention and subsequently studies to what extent these underlying assumptions (theories of change) are realistic (Weiss, 1995; Pawson and Tilley, 1997). According to Dana and Dana (2005), flexible and inductive designs of qualitative research are more appropriate for yielding new theories and understanding (community) entrepreneurs' dynamic interactions with their environment than hypothetico-deductive (quantitative) methodologies. Qualitative empirical research can also reveal the degree to which local communities are actually involved in CDCs and CEs and the ways in which (new) partnerships are formed between community organizations, state, local, and federal agencies (DeLuca and Rosenblatt, 2013, p.11). 
Second, we endorse the viewpoint that both the 'consumption' and 'production' of social capital are still little understood in the context of CEs (Somerville \& McElwee, 2011: 323). Hence, research should reveal how community enterprise can harness social capital in local communities (including ones experiencing gentrification or becoming immigrant enclaves) and how social capital can be used (more effectively) to achieve positive outcomes through mobilizing volunteers, board members and paid staff. Again, quantitative research will probably not advance our knowledge. From their literature review on measuring social capital in the entrepreneurial process, Ferri and colleagues (2009) have concluded that qualitative 'measurement' of intangible factors in the entrepreneurial process is needed to reveal rich contextual information and solve the lack of consensus on accepted definitions of social capital in entrepreneurial contexts.

Third, in terms of management, research should examine in more depth the role that is played by $\mathrm{CDC} / \mathrm{CE}$ boards, relative to the director, in establishing the mission of the $\mathrm{CDC} / \mathrm{CE}$, in governing the organization, and in establishing the importance of the relationship between the board and executive director in influencing agency effectiveness (see also Bacq and Janssen, 2011, p. 391). Fourth, future research should investigate the relative importance of the benefits and costs of strategic targeting versus needs-based targeting.

Finally, more attention is needed for entrepreneurial 'cycles'. As mentioned in the Introduction, resident-organized and social entrepreneurial activities are currently seen as solutions for deficiencies in public services and neighbourhood regeneration efforts. Just as any entrepreneurial start-up or activity, CDCs and CEs may fail, whether or not they have been successful in the short or long run. Honig and Dana (2008) have studied two rural entrepreneurial communities that temporarily showed social and economic success, but regressed over time or went through periods marked by either unusual success or unusual failure. Therefore, a longitudinal approach towards the study of community-based entrepreneurship, especially in urban areas, will surely advance the knowledge on the potential of community entrepreneurship in the context of neighbourhood revitalization (see also Ratten et al., 2010).

\section{Acknowledgments}

This paper is the result of the research stay of David Varady as Visiting Professor at Delft University of Technology, Faculty of Architecture and the Built Environment, Department OTB, from May till July, 2014. During this stay, Varady collaborated with the other authors in conducting the literature review and writing the paper. No official funding applies.

\section{References}

Accordino, J., and Fasulo, F. (2013), "Fusing technical and political rationality in community development: A prescriptive model of efficiency-based strategic geographic targeting", Housing Policy Debate, Vol. 23, No. 4, pp. 615-642.

Bacq, S., and Janssen, F. (2011), "The multiple faces of social entrepreneurship: A review of definitional issues based on geographical and thematic criteria", Entrepreneurship \& Regional Development, Vol. 23 No. 5-6, pp. 373-403.

Bailey, N. (2012), "The role, organization and contribution of community enterprise to urban regeneration policy in the UK", Progress in Planning, Vol. 77, pp. 1-35. 
Beauregard, R. A. (2013), Strategic thinking for distressed neighborhoods. In M. Dewar and J. M. Thomas (Eds.), The City After Abandonment, University of Pennsylvania Press, Philadelphia, PA, pp. 227-243.

Berke, P. R., and Godschalk, D. (2009), "Searching for the good plan: A meta-analysis of plan studies", Journal of Planning Literature, Vol. 23, No. 3, pp. 227-240.

Bjørnå, H. and Aarsæther, N. (2010), "Local government strategies and entrepreneurship", International Journal of Innovation and Regional Development, Vol. 2 No. 1, pp. 5065.

Bostic, R. W. (2014), “CDBG at 40: Opportunities and obstacles”, Housing Policy Debate, Vol. 24, No. 1, pp. 297-302.

Bratt, R. G. (2008), "Non-profit and for-profit developers of subsidized rental housing: Comparative attributes and collaborative opportunities", Housing Policy Debate, Vol. 19, No. 2, pp.

Bratt, R. G. (2012), "The quadruple bottom line and nonprofit housing organizations in the United States", Housing Policy Debate, Vol. 27, No. 4, pp. 438-456.

Bratt, R. G., and Reardon, K. M. (2013), Beyond the ladder: New ideas about resident roles in contemporary community development in the United States. In N. Carmon and S. Fainstein (Eds.), Policy, Planning and People, University of Pennsylvania Press, Philadelphia, PA, pp. 356-382.

Briggs, X. d. S. (2014), "Looking back and looking ahead: CDBG and the future of federal urban policy", Housing Policy Debate, Vol. 24, No. 1, pp. 303-309.

Brooks, L., and Sinitsyn, M. (2014), "Where does the boat leak? Sending money to the poor via the Community Development Block Grant Program”. Housing Policy Debate, Vol. 24, No. 1, pp. 119-171.

Center for Effective Government. (2005), "House considers CDBG but avoids attaching PART", available at: http://www.foreffectivegov.org/node/2453 (accessed 13 January 2015).

Collinson, R. A. (2014), "Assessing the allocation of CDBG to community development need", Housing Policy Debate, Vol. 24, No. 1, pp. 91-118.

Cowan, S. M., Rohe, W., and Baku, E. (1999), "Factors influencing the performance of community development corporations". Journal of Urban Affairs, Vol. 21, No. 3, pp. 325-340.

Dana, L. P. (1995), "Entrepreneurship in a remote sub-Arctic community", Entrepreneurship Theory and Practice, Vol. 20, pp. 57-72.

Dana, L. P., and Dana, T. E. (2005), "Expanding the scope of methodologies used in entrepreneurship research", International Journal of Entrepreneurship and Small Business, Vol. 2 No. 1, pp. 79-88.

Davis, J. E. (Ed.) (2010), The Community Land Trust Reader, Lincoln Institute of Land Policy, Cambridge, MA.

DCLG (2011a), The Localism Act: Explanatory Notes, Department for Communities \& Local Government, London.

DCLG (2011b) Regeneration to enable growth: What Government is doing in support of community-led regeneration, Department for Communities \& Local Government, London.

DCLG (2012) Regeneration to enable growth: A toolkit supporting community-led regeneration, Department for Communities \& Local Government, London.

DeFilippis, J. (2001), "The myth of social capital in community development", Housing Policy Debate, Vol. 12, No. 4, pp. 781-806.

DeFilippis, J., Fisher, R., and Shragge, E. (2010), Contesting Community: The Limits and Potential of Community Organizing, Rutgers University Press, New Brunswick, NJ. 
DeLuca, S., and Rosenblatt, P. (2013), Sandtown-Winchester-Baltimore's daring experiment in urban renewal: what are the lessons learned? The Abell Report, Vol. 26, No. 8. Available at: http://www.abell.org/pubsitems/arn1113.pdf (accessed 13 January 2015).

Dewar, M., Kelly, C., and Morrison, H. (2013), Planning for better, smaller places after population loss: Lessons from Youngstown and Flint. In M. Dewar and J. M. Thomas (Eds.), The City After Abandonment, University of Pennsylvania Press, Philadelphia, PA, pp. 290-316.

Dewar, M., and Thomas, J. M. (2013), Introduction: What does the city become after abandonment? In M. Dewar and J. M. Thomas (Eds.), The City After Abandonment, University of Pennsylvania Press, Philadelphia, PA, pp. 1-14.

Ehrenfeucht, R., and Nelson, M. (2013), Recovery in a shrinking city: Challenges in rightsizing post-Katrina New Orleans. In M. Dewar and J. M. Thomas (Eds.), The City After Abandonment, University of Pennsylvania Press, Philadelphia, PA, pp. 137-150.

Elkington, J. (1998), "Partnerships from cannibals with forks: The triple bottom line of 21st century business". Environmental Quality Management, Vol. 8, No. 1, pp. 37-51.

Erickson, D. J. (2009), The Housing Policy Revolution: Networks and Neighborhoods, Urban Institute Press, Washington, DC.

Evans, M. (2008), "Who is for community participation? Who is community participation for? Exploring the well-being potential for involvement in regeneration", Education, Knowledge and Economy, Vol. 2, No. 3, pp. 163-173.

Fainstein, S. S. (2010), The Just City, Cornell University Press, Ithaca, NY.

Ferri, P. J., Deakins, D., and Whittam, G. (2009), "The measurement of social capital in the entrepreneurial context", Journal of Enterprising Communities: People and Places in the Global Economy, Vol. 3 No. 2, pp. 138-151.

Fraser, J., Lepofsky, J., Kick, E., and Williams, J. (2003), "The construction of the local and the limits of contemporary community-building in the United States", Urban Affairs Review, Vol. 38, No. 3, pp. 417-445.

Freeman, L. (2006), There Goes the 'hood': Views of the Neighborhood from the Ground Up, Temple University Press, Philadelphia, PA.

Galster, G., Tatian, P. and Accordino J. (2006), "Targeting investments for neighborhood revitalization", Journal of the American Planning Association, Vol. 72, No. 4, pp. 457-474.

Galster, G., Walker, C., Boxall, P., and Johnson, J. (2004), "Measuring the impact of community development block grants on urban neighborhoods", Housing Policy Debate, Vol. 15, No. 4, pp. 903-934.

Gawell, M., Johannisson, B. and Lundqvist, M. (2009), Entrepreneurship in the Name of Society. Reader's Digest of a Swedish Research Anthology, The Knowledge Foundation, Stockholm.

Glickman, N. J., and Servon, L.J. (2003), "By the Numbers: Measuring Community Development Corporations' Capacity", Journal of Planning Education and Research, Vol. 22, No. 3, pp. 240-56.

Greenberg, D., Verma, N., Dillman, K., and Chaskin, R. (2010), Creating a Platform for Sustained Neighborhood Improvement: Interim Findings from Chicago's New Communities Program, Manpower Demonstration Research Corporation, New York.

Hastings, A., Bramley, G., Bailey, N., and Watkins, D. (2012), Serving deprived communities in a recession, Joseph Rowntree Foundation, York.

Honig, B., and Dana, L. P. (2008). "Communities of disentrepreneurship: A comparative cross-national examination of entrepreneurial demise", Journal of Enterprising Communities: People and Places in the Global Economy, Vol. 2, No. 1, pp. 5-20.

Husock, H. (2003), America's Trillion-Dollar Housing Mistake, Ivan Dee, Chicago, IL. 
Johnson, K. (2004) "Community development corporations, participation, and accountability: The Harlem Urban Development Corporation and the Bedford-Stuyvesant Restoration Corporation". The Annals of the American Academy of Political and Social Science, Vol. 594, pp. 187-89.

Joice, P. (2010), "Neighborhood stabilization program", Cityscape: A Journal of Policy Development and Research, Vol. 13, No. 1, pp. 135-141.

Keating, W., Krumholz, N. and P. Star (1991), "Current Status and Future Prospects for Community Development Corporations", Journal of Planning Literature, Vol. 6, No. 1, pp. 34-37.

Kisby, B. (2010), “The Big Society: power to the people?” The Political Quarterly, Vol. 81, No. 4, pp. 484-491.

Kretzmann, J. P., and McKnight, J. L. (1993), Building communities from the inside out, Asset-Based Community Development Institute, Northwestern University, Evanston, IL.

Krohn-Hansen, C. (2013), Making New York Dominican: Small Business, Politics, and Everyday Life, University of Pennsylvania Press, Philadelphia, PA.

Lawless, P. (2011), "Big Society and community: lessons from the 1998-2011 New Deal for Communities Programme in England". People, Place and Policy Online, Vol. 5, No. 2, pp. 55-64.

Locality (2014), Vision and Mission. Available at: http://locality.org.uk/about/mission-vision/ (accessed 13 January 2015).

Mayer, N. S., and Temkin, K. (2006), Housing partnerships: The Work of Large Scale Regional Nonprofits in Affordable Housing, Urban Institute Press, Washington DC.

Minnery, J. (2007), "Stars and their supporting cast", Urban Policy and Research, Vol. 25, No. 3, pp. 333-344.

National Congress for Community Economic Development NCCED (2005), Reaching New Heights: Trends and achievements of Community-based Development Organizations, NCCED, Washington DC.

Newman, S. J., and Schnare, A. B. (1992), Beyond Bricks and Mortar, Urban Institute, Washington DC.

Pawson, R. and Tilley, N. (1997), Realistic Evaluation, Sage Publications, London.

Pearce, J (2003). Social enterprise in Anytown, Calouste Gulbenkian Foundation, London.

Peredo, A., and Chrisman, J. (2006), "Toward a theory of community-based enterprise", Academy of Management Review, Vol. 31 No. 2, pp. 309-328.

Pooley, K. B. (2014), "Using Community Development Block Grant dollars to revitalize neighborhoods: The impact of program spending in Philadelphia", Housing Policy Debate, Vol. 24, No. 1, pp. 172-191.

Ratten, V., Welpe, I., and Dana, L. P. (2010), "Editorial: Community-based entrepreneurship: towards a future research agenda", International Journal of Innovation and Regional Development, Vol. 2 No. 1/2, pp. 1-3.

Rich, M. J. (2014), "Community Block Grants at 40: Time for a makeover", Housing Policy Debate, Vol. 24, No. (1, pp. 46-90.

Rohe, W. M., and Galster, G. C. (2014), "Guest editors' introduction: The Community Development Block Grant Program turns 40: Proposals for program expansion and reform", Housing Policy Debate, Vol. 24, No. 1, pp. 3-13.

Rusk, D. (1999), "Saving farms and saving cities: Sprawl, race and concentrated poverty", Community News, Vol. 11, No. 1, pp 1-5.

Ryan, B. D. (2013), Rightsizing shrinking cities. In M. Dewar and J. M. Thomas (Eds.), The City After Abandonment, University of Pennsylvania Press, Philadelphia, PA, pp. 268288 . 
Saegert, S. (2006), "Building civic capacity in urban neighborhoods: An empirically grounded anatomy", Journal of Urban Affairs, Vol. 28, No. 3, pp. 275-294.

Scally, C. P. (2012), "Community development corporations, policy networks, and the rescaling of community development advocacy", Environment \& Planning C, Vol. 30, pp. 712-729.

Scally, C. P. (2012/2013), Restoring confidence in the CDC model, Shelterforce Online. Available at:

http://www.shelterforce.org/article/3329/restoring_confidence_in_the_cdc_model (accessed 13 January 2015).

Schatz, L. (2013), Decline-oriented urban governance in Youngstown, Ohio. In M. Dewar and J. M. Thomas (Eds.), The City After Abandonment, University of Pennsylvania Press, Philadelphia, PA, pp. 87-103.

Smith, R. (2012), "Developing and animating enterprising individuals and communities", Journal of Enterprising Communities: People and Places in the Global Economy, Vol. 6, No. 1, pp. 57-83.

Somerville, P., and McElwee, G. (2011), "Situating community enterprise: A theoretical exploration", Entrepreneurship \& Regional Development, Vol. 23 No. 5-6, pp. 317330.

Stoecker, R. (1997), "The CDC model of urban redevelopment", Journal of Urban Affairs, Vol. 19, No. 1, pp. 1-22.

Sundin, E. (2011), "Entrepreneurship and social and community care", Journal of Enterprising Communities: People and Places in the Global Economy, Vol. 5, No. 3, pp. 212-222.

Thake, S. (1995), Staying the Course: The Role and Structures of Community Regeneration Organizations, Joseph Rowntree Foundation, York.

Thomas, J. M. (2013), Targeting strategies of three Detroit CDCs. In M. Dewar and J. M. Thomas (Eds.), The City After Abandonment, University of Pennsylvania Press, Philadelphia, PA, pp. 197-224.

Vale, L. (2013), Purging the Poorest: Public Housing and the Design Politics of TwiceCleared Communities, University of Chicago Press, Chicago.

Van Meerkerk, I., Boonstra, B., and Edelenbos, J. (2013), "Self-Organization in Urban Regeneration: A Two-Case Comparative Research", European Planning Studies, Vol. 21, No. 10, pp. 1630-1652.

Walker, C., Hayes, C., Galster, G., Boxtall, P., and J., J. (2002), The Impact of CDBG spending on urban neighborhoods, The Urban Institute, Washington, DC.

Weiss, C. (1995), Nothing as Practical as Good Theory: Exploring Theory-based Evaluation in Complex Community Initiatives for Children and Families'. In: J. Connell, A. Kubisch, L. Schorr and C. Weiss (Eds), New Approaches to Evaluating Community Initiatives, Aspen Institute, Washington DC.

Wells, P. (2011), "Prospects for a Big Society? (Special Issue)", People Place and Policy Online, Vol. 5, No. 2, pp. 50-54.

Williams, C. (2011), "Entrepreneurship, the informal economy and rural communities", Journal of Enterprising Communities: People and Places in the Global Economy, Vol. 5 No. 2, pp. 145-157.

Zimmer, A. and Bräuer, S. (2014), The Development of Social Entrepreneurs in Germany Literature Review. EU KP7-EFESEIIS Project, Westfälische Wilhelms University, Münster.

Zwiers, M., Bolt, G., Ham, M. van and Kempen, R. van (2014), "Neighborhood Decline and the Economic Crisis", IZA Working Paper No. 8749, IZA, Bonn. 